Letto, K. R., Y. F. Wiersma, J. Brazil, and B. Rodrigues. 2015. Bald eagle (Haliaeetus leucocephalus) population increases in Placentia Bay, Newfoundland: evidence for habitat saturation? Avian Conservation and Ecology 10(1): 4. http://dx.doi.org/10.5751/ACE-00729-100104 Copyright (C) 2015 by the author(s). Published here under license by the Resilience Alliance.

\title{
Bald eagle (Haliaeetus leucocephalus) population increases in Placentia Bay, Newfoundland: evidence for habitat saturation?
}

\author{
Karla R. Letto ${ }^{1,2}$, Yolanda F. Wiersma ${ }^{1}$, Joe Brazil ${ }^{3}$ and Bruce Rodrigues ${ }^{3}$ \\ ${ }^{1}$ Department of Biology, Memorial University, St. John's, Newfoundland and Labrador, ${ }^{2}$ Nunavut Wildlife Management Board, \\ Iqaluit, Nunavut, ${ }^{3}$ Wildlife Division, Department of Environment and Conservation, Government of Newfoundland and Labrador, \\ Corner Brook, Newfoundland and Labrador
}

\begin{abstract}
Across North America, Bald Eagle (Haliaeetus leucocephalus) populations appear to be recovering following bans of DDT. A limited number of studies from across North America have recorded a surplus of nonbreeding adult Bald Eagles in dense populations when optimal habitat and food become limited. Placentia Bay, Newfoundland is one of these. The area has one of the highest densities of Bald Eagles in eastern North America, and has recently experienced an increase in the proportion of nonbreeding adults within the population. We tested whether the observed Bald Eagle population trends in Placentia Bay, Newfoundland during the breeding seasons 1990-2009 are due to habitat saturation. We found no significant differences in habitat or food resource characteristics between occupied territories and pseudo-absence data or between nest sites with high vs. low nest activity/occupancy rates. Therefore there is no evidence for habitat saturation for Bald Eagles in Placentia Bay and alternative hypotheses for the high proportion of nonbreeding adults should be considered. The Newfoundland population provides an interesting case for examination because it did not historically appear to be affected by pollution. An understanding of Bald Eagle population dynamics in a relatively pristine area with a high density can be informative for restoration and conservation of Bald Eagle populations elsewhere.
\end{abstract}

\section{Hausse de la population de Pygargue à tête blanche (Haliaeetus leucocephalus) dans la baie de Placentia, Terre-Neuve : indice de la saturation de l'habitat?}

RÉSUMÉ. Partout en Amérique du Nord, les populations de Pygargue à tête blanche (Haliaeetus leucocephalus) semblent se remettre à la suite de l'interdiction d'utilisation du DDT. Selon certaines recherches menées en Amérique du Nord, un surplus de pygargues adultes non nicheurs a été observé lorsque la densité des populations est élevée et que les conditions optimales d'habitat et de ressources alimentaires deviennent limitantes. La baie de Placentia, à Terre-Neuve, présente une telle situation : elle est l'hôte d'une densité de pygargues parmi les plus élevées de l'est de l'Amérique du Nord et a récemment connu une hausse du nombre d'adultes non nicheurs dans la population. Nous avons examiné si la saturation de l'habitat pouvait expliquer la tendance de la population de pygargues dans la baie de Placentia au cours des saisons de nidification de 1990 à 2009. Aucune différence significative des caractéristiques de l'habitat ou des ressources alimentaires n'a été observée entre les territoires occupés et ceux apparemment inoccupés, ni entre les sites de nidification montrant une forte activité de nidification/taux d'occupation et ceux en montrant une faible. Ainsi, il n'y a pas de preuve de saturation de l'habitat des pygargues dans la baie de Placentia, de sorte que d'autres hypothèses pouvant expliquer cette forte proportion d'adultes non nicheurs devraient être considérées. La population de Terre-Neuve représente un cas intéressant à examiner parce qu'elle n'aurait pas été affectée par la pollution ayant eu cours dans le passé. La compréhension de la dynamique de population des pygargues dans une région relativement vierge et hôte d'une densité élevée peut contribuer à la restauration et à la conservation des populations de pygargues ailleurs dans l'aire de reproduction.

Key Words: Bald Eagle; habitat saturation; Haliaeetus leucocephalus; nest occupancy; Newfoundland; nonbreeding adults

\section{INTRODUCTION}

Habitat saturation was initially proposed as a hypothesis to explain delayed dispersal in co-operatively breeding birds (Emlen 1982). However, habitat saturation has no formal definition, and has been applied to species not known to exhibit co-operative breeding. Selander (1964, as cited in Koenig et al. 1992:117) defined habitat saturation as the condition in which young are unable to establish "adequate territory and breeding." However, Koenig et al. (1992) pointed out that "adequate territory" is an arbitrary concept and that there may be competing hypotheses for delayed breeding. Koenig et al. (1992) postulated that "floaters" may or may not be "helpers." They argued that the case of nonbreeders participating in co-operative breeding may be better explained by kin selection rather than habitat saturation. However, in birds such as raptors which only rarely (Kimball et al. 2003) exhibit co-operative breeding, the more parsimonious explanation for a high proportion of nonbreeding "floaters" may indeed be habitat saturation.

Across North America, Bald Eagle (Haliaeetus leucocephalus) populations have experienced increases since the ban of DDT (Grier 1982, Kirk and Hyslop 1998, Jenkins and Sherrod 2005, Watts et al. 2008), to the point where they have been delisted from 
Table 1. Comparison of adult Bald Eagle (Haliaeetus leucocephalus) density and the proportion of nonbreeding adults across North America.

\begin{tabular}{|c|c|c|c|c|}
\hline Location & Study year(s) & $\begin{array}{l}\text { Adult density (\#/km } \\
\text { coastline) }\end{array}$ & $\begin{array}{c}\text { Nonbreeding } \\
(\%)\end{array}$ & Source \\
\hline British Columbia & 1990 & $0.37-0.39$ & 56 & Hodges et al. 1984 \\
\hline SE Alaska & 1970-1972, 1979 & $0.79-0.94$ & 55 & Hansen and Hodges 1985 \\
\hline Yellowstone National Park & 1972-1974 & 0.173 & 39 & Swenson et al. 1986 \\
\hline Snake Unit, Wyoming & $1978-1979$ & 0.079 & 19 & Swenson et al. 1986 \\
\hline Amchitka Island, Alaska & $1971-1972$ & $0.643-0.722$ & 19 & Sherrod et al. 1976 \\
\hline Placentia Bay, NL & $1990-2009$ & $0.084-0.407$ & 54.4 & Letto 2010 \\
\hline Besnard Lake, Saskatchewan & $1976-1990$ & 0.303 & 27.4 & Gerrard et al. 1992 \\
\hline $\begin{array}{l}\text { Nemeiben Lake, } \\
\text { Saskatchewan }\end{array}$ & 1986 & $0.054-0.059$ & $11-18$ & Dzus and Gerrard 1989 \\
\hline
\end{tabular}

the U.S. Endangered Species list, though still subject to ongoing monitoring (Watts and Duerr 2010). Along with these population increases have come increases in the proportion of nonbreeding adults in many populations, albeit with a high degree of variation (Table 1). Understanding what might drive these variations in population structure may be valuable for informing conservation strategies to restore and maintain Bald Eagle populations. Hansen and Hodges (1985) and Jenkins and Sherrod (2005) hypothesized that the Bald Eagle populations with a very high proportion of nonbreeding adults that they observed in Alaska and Chesapeake Bay, respectively, may be an indicator of habitat saturation. Hansen (1987) used experiments with food supplementation to provide further evidence that Bald Eagle habitat in Alaska might be saturated.

Habitat saturation is not well-defined, but here we take the Salendar (1964, as cited in Koenig et al. 1992) concept that habitat saturation occurs when the habitat conditions are such that young adults are not able to establish territories. Therefore, in a population where the habitat is saturated, there are expected to be differences in habitat attributes between active vs. empty territories as well as gradients of habitat quality that match gradients of nest productivity. Habitat is an often ambiguously defined term; Hansen (1987), in his investigation of habitat saturation of Bald Eagles in Alaska, described two components of habitat, "habitat characteristics," i.e., environmental and ecological attributes, and "food quality."

Placentia Bay, off the island of Newfoundland, Canada (Fig. 1), has one of the highest densities of Bald Eagles in eastern North America (Dominguez 1998) and is a site where we hypothesize habitat saturation may be occurring. Nest surveys have been conducted annually by the Provincial Wildlife Division between 1990 and 2009. These show a steady increase in population density, driven largely by increases in nonbreeding adults (Fig. 2; Letto 2010). The increase in nonbreeding adults within this population might be an indicator of habitat saturation and the population trends in Placentia Bay appear to be consistent with Brown's (1969) Level 3 condition. Level 3 is defined as having all potential breeding habitats, whether of poor or rich quality, occupied by a territorial pair and the presence of a surplus of nonbreeders that would otherwise be able to breed (Brown 1969). This high proportion of nonbreeding "floaters" may be due to habitat saturation, or to other competing hypotheses for delayed breeding (Koening et al. 1992). Here, we use this long-term data set together with habitat models to test for evidence of habitat saturation in Bald Eagles in Placentia Bay. We also test the hypothesis that there are no adequate territories for Bald Eagles to move into, which would provide further evidence in support of habitat saturation.

Fig. 1. Location of Newfoundland in Eastern Canada (rectangle in top left map). Location of study area, Placentia Bay, in southeast Newfoundland (rectangle in Newfoundland map). Close up of Placentia Bay showing the location of past (Argentia U.S. Naval Base and Long Harbour phosphorus plant) and present (Come By Chance oil refinery, Whiffen Head offshore oil transhipment facility and Marystown shipyard) industries (large center map).

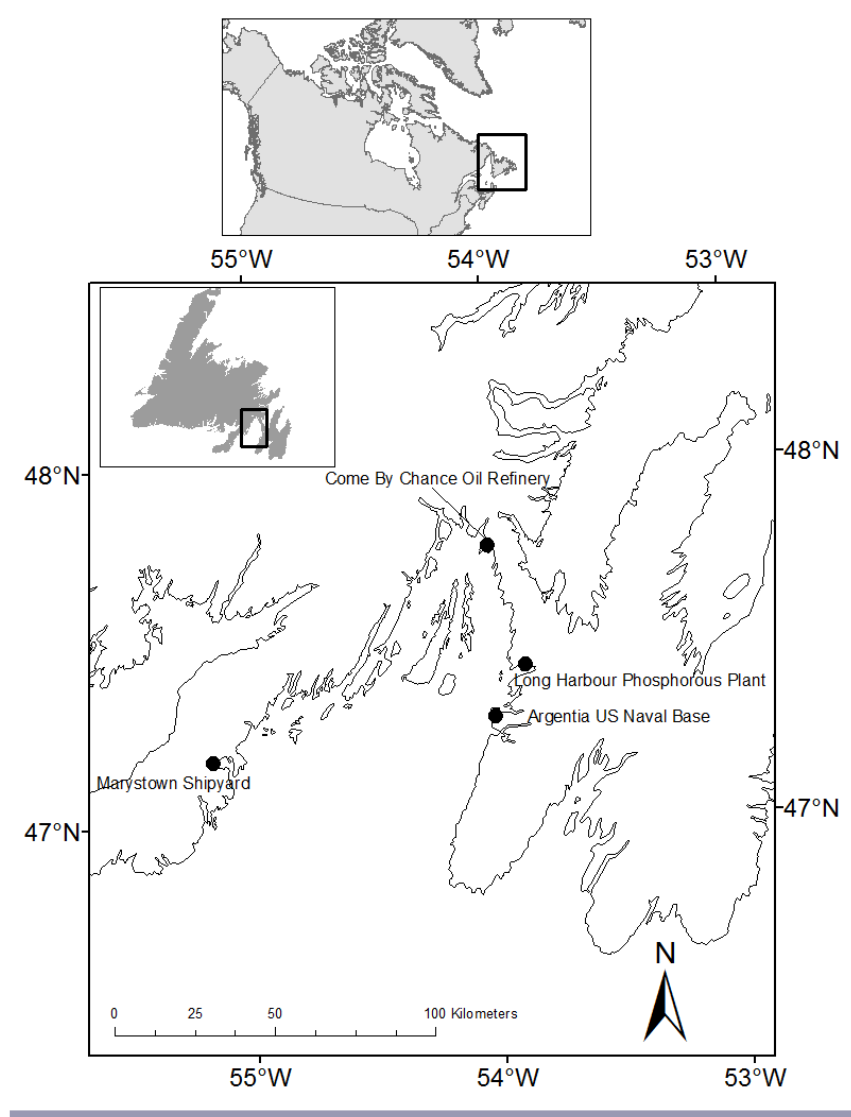


Fig. 2. Top panel: Adult Bald Eagle (Haliaeetus leucocephalus) density in Placentia Bay, NL across survey years 1990 to 2009 (black diamonds). Density of Adults Bald Eagles breeding (dark grey triangles) and density of adult Bald Eagles not breeding (light grey squares). Bottom panel: Proportion of adult Bald Eagles breeding in Placentia Bay from 1990-2009.
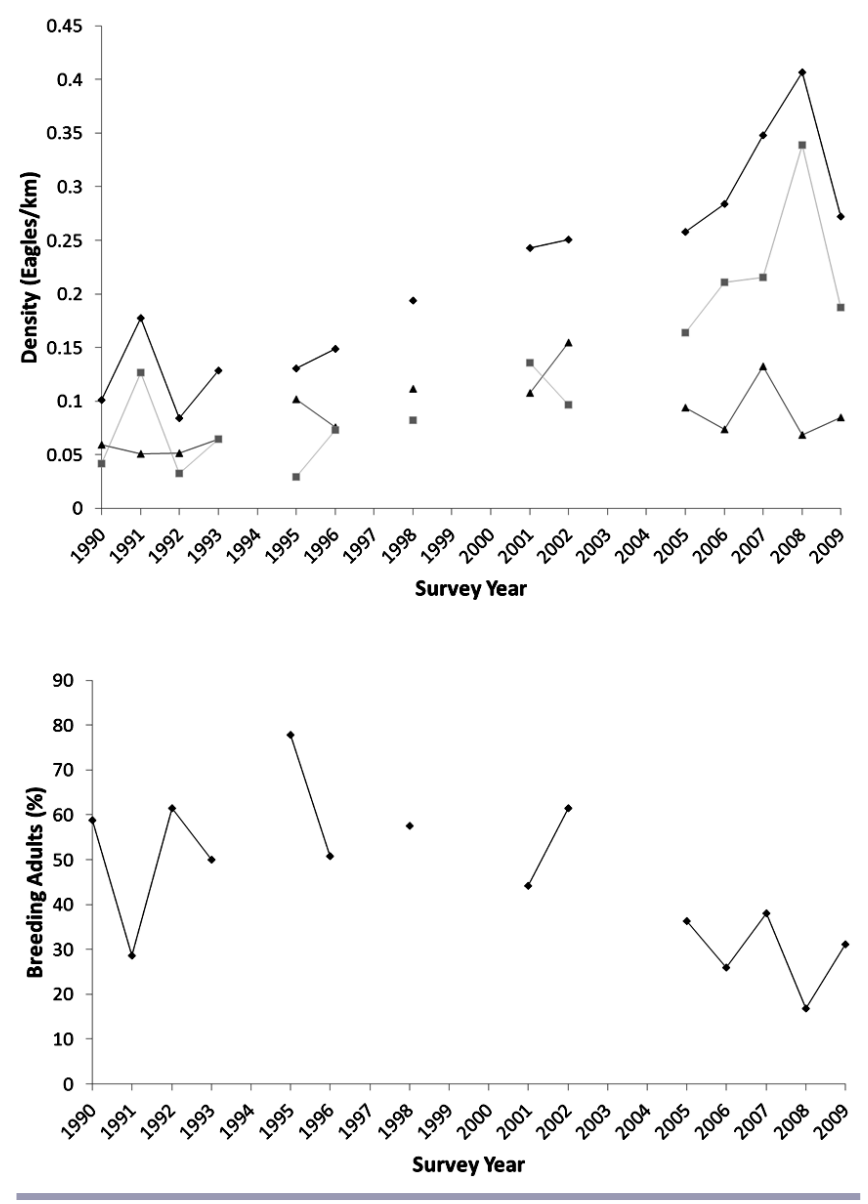

Because the habitat characteristics that Bald Eagles select for in establishing new territories are not well-studied in this area, we first developed predictive habitat models for Bald Eagle territories by using data from nest sites that were occupied within the 19year survey period compared with pseudo-absence data, i.e., unoccupied nest sites. Using multimodel inference (Burnham and Anderson 2002), we identified habitat parameters of importance for Bald Eagles. We then applied frequentist statistics (specifically Welch's t-test) to test whether these important habitat characteristics differed between occupied and unoccupied territories. We also compared these habitat parameters from our predictive models across nest sites with variable degrees of nest site activity/occupancy through the 19 -year survey period. We expected gradients in the values of habitat characteristics to match gradients of nest activity/occupancy rates. If habitat saturation was occurring then we expected to see differences in the habitat characteristics between territories with occupied nests and pseudo-absence sites (representing potential territories). Alternatively, if we found no differences in habitat quality between sites with different levels of nest activity/occupancy, or sites with and without active nests, then the observed increase in nonbreeders must have been due to something other than limited availability of habitat to establish new territories and therefore habitat saturation was not the reason for the high observed proportion of nonbreeding adults in the Placentia Bay Bald Eagle population.

A better understanding of the Bald Eagle population in Placentia Bay can help inform conservation and management of the species elsewhere in North America. Bald Eagle populations have been documented to be stable or increasing in many parts of the continent, and appear to do well even in close proximity to urban areas (e.g., Thompson and McGarigal 2002, Millsap et al. 2004) and urban landfill sites (Elliott et al. 2006). Understanding the role that subadults and nonbreeding adults play in population recovery can be important. For example, Elliott et al. (2006) observed that a small proportion of the subadults were "refuse specialists," obtaining a large proportion of their food energy from human garbage. This behavior may limit subadult breeding opportunities, or it may be (as Elliott et al. 2006 posit) a foraging strategy to compensate for lower hunting efficiency. In a few parts of the continent, Bald Eagle populations are declining (e.g., Baldwin et al. 2012) and appear to be experiencing declines in territory occupancy. A further understanding of how habitat and food resources may limit populations can inform management and conservation strategies across the range of Bald Eagles.

\section{METHODS}

\section{Study area}

Placentia Bay is located on the southeastern coast of the Island of Newfoundland, Canada, at approximately $47^{\circ} 37.499^{\prime} \mathrm{N}, 54^{\circ}$ 14.947'W. The study area within Placentia Bay consisted of the harbor head beginning with Bordeaux Island and as far south as Long Point on the western coastline, as well as the major islands along the western coastline, Merasheen Island, Long Island, Great Seal Island, and the Ragged Islands (Fig. 1). In addition to these there are 365 islands and reefs most of which are uninhabited or have only seasonal cabin users. The total length of coastline surveyed each year varied between 276 and $450 \mathrm{~km}$ depending on survey effort, which was largely constrained by weather conditions.

Placentia Bay's climate is classified as midboreal. The area is characterized by relatively short, cool, wet summers and mild, wet winters. Precipitation and fog are very common in the area (Damman 1983). The vegetative assemblage within the study area is classified as an Oceanic Midboreal ecosystem. Coniferous forest, consisting mostly of black spruce (Picea mariana) and balsam fir (Abies balsamea), dominate the sheltered coastal and inland areas (Damman1983). These forests are naturally sparse because of thin soils and a cool growing season. Forest harvest, other than small-scale domestic harvest, is absent, and disturbance through fire was nonexistent during the study period. The forest is not considered commercially productive and is not part of the provincial Forest Resource Inventory.

Placentia Bay is considered an environmentally sensitive area, hosting an abundant and diverse marine ecosystem (CCMC 2004). It sustains one of the richest fish biomasses in 
Newfoundland waters, various seabird colonies including Northern Gannet (Morus bassanus), Atlantic Puffin (Fratercula arctica), Great Cormorant (Phalacrocorax carbo), Razorbill (Alca torda), Thick-billed Murre (Uria lomvia), and Common Murre (Uria aalge), breeding and wintering grounds for Bald Eagles, and feeding grounds for several species of seals and whales (Dominguez 1998). Many of these marine species are potential prey for Bald Eagles, and their abundances have varied through time in complex ways, not all of which have been well documented in Placentia Bay.

\section{Survey methods}

The Newfoundland and Labrador Department of Environment and Conservation, Wildlife Division has conducted its Bald Eagle survey annually since 1984. Surveys were conducted in late Juneearly July, which is consistent with the chick-rearing stage of the breeding season in Newfoundland. The survey years 1990-2008 were all led by the same individual (JB) and they were taken over by a second individual (BR) who trained with the original surveyor before going out alone. Therefore we are confident that counting methods across years are consistent. The survey procedure involved travelling approximately $50 \mathrm{~m}$ offshore along the study area's coastline in a $7.3 \mathrm{~m}(24 \mathrm{ft})$ fiberglass Seagull inboard motor speed boat at an approximate cruising speed of $16-20 \mathrm{~km} / \mathrm{hr}$. Surveys in early years were carried out in a $5.5 \mathrm{~m}$ (18 ft) open speedboat with outboard motors. Survey crews (up to 3 individuals plus a boat captain) scanned the shoreline with binoculars and recorded the location of breeding and nonbreeding adults, and immature Bald Eagles, as well as active, inactive, and occupied nest territories. An active nest site was defined as one in which chicks were observed, an adult was sitting low on the nest (incubating), or the adult was vocalizing near (within $\sim 100 \mathrm{~m}$ ) the nest. An inactive nest was one in which no Bald Eagles were observed near the nest, or if any observed Bald Eagles flew silently away from the nest without returning to the area. A nest classified as an occupied site was one in which at least one adult was perched near a nest and remained within that area without vocalizing. A nest classified as such could not be confidently classified as being active or inactive during that particular breeding season. Throughout this paper, nest site refers to the general area within which a nest is located. We set nesting territories as a $2.6 \mathrm{~km}^{2}$ (Grier et al. 1983) circular area with the nest location as the centroid.

Survey years 1984-1989 were considered trial years that were used to test survey procedures that would be suitable for the local conditions and that would be feasible over the longer term and these data were not used in this analysis. We did not conduct surveys in 1994, 1997, 1999, 2000, 2003, and 2004 because of weather or staffing constraints. We digitized the location of Bald Eagle sightings and nest sightings, as well as the survey route travelled each survey year to standardize counts by survey effort in ArcGIS (version 9.3., ESRI, Redlands, California, USA).

\section{GIS analysis}

Within the study area we generated 163 pseudo-absence points using Hawth's Tools in ArcGIS (version 9.3., ESRI, Redlands, California, USA) to represent unused nest sites. The pseudoabsence sites were all located within $5 \mathrm{~m}$ of the shoreline (to be in a similar location along the coast as those nests observable in the boat surveys) and separated from both each other and true nest locations by a minimum distance of $910 \mathrm{~m}$ (breeding territory radius). Because the areas of coastline in which these pseudoabsence points were located were surveyed annually for Bald Eagles, the probability that these points were false absences is low and our pseudo-absence points were a reasonable approximation of "true absence" data (Fielding and Bell 1997, Phillips et al. 2009).

In this study we divided "habitat" into "habitat" and "food resource" characteristics, similar to Hansen (1987). We used four habitat parameters and four food resource parameters to characterize habitat in Bald Eagle territories in Placentia Bay. The habitat characteristics analyzed included the nest site elevation, the proportion of the territory composed of sparse coniferous forest and water, and whether the nest site was located on the "mainland" part of the island of Newfoundland (hereafter the "mainland") or on an island within the bay. Previous research has shown that Bald Eagles prefer to nest on smaller islands instead of the mainland (Gerrard et al. 1975, Livingston et al. 1990), likely because of reduced numbers of predators and more opportunities to forage over water in all directions.

The food resource variables analyzed included the distance from the nest/pseudo-absence site to the nearest capelin (Mallotus villosus) aggregation site, Atlantic herring (Clupea harengus) aggregation site, major capelin spawning beach (defined as beaches where spawning occurs every year), and average capelin spawning beach (defined as beaches where spawning occurs at least occasionally) because these species are known to be important for Bald Eagles and other Bald Eagle prey species (Gende et al. 1997). These locations were mapped by Fisheries and Oceans Canada and are based on long-term local ecological knowledge (LEK) of fishers and community members (Sjare et al. 2003). Because Bald Eagles are generalists, and also scavengers, these data do not represent the full range of food resources available. However, these were the only resources for which we had geographic data. It is rare for species distribution models to actually include food resources (Austin 2002). GIS data used in the analysis are summarized in Table 2. Analysis of Bald Eagle habitat in other North American locations found that eagles choose nest sites in mature and old-growth forest with open canopies and in close proximity to a large body of water (Andrew and Mosher 1982, Buehler 2000). The open canopy is believed to be preferred by Bald Eagles because of their inability to maneuver through dense forest stands. Large water bodies might offer more foraging opportunities. Therefore, we expected that the majority of nest territories within Placentia Bay would have a larger proportion of sparse coniferous forest and water within them than other habitat cover types, and if habitat saturation had indeed occurred, that these proportions would be significantly lower in pseudo-absence sites. However, habitat characteristics are not usually related to nest success (Buehler 2000). We predicted that these two parameters would be weakly related to the frequency of nest site activity/occupancy and that food parameters would be more important.

We created circular buffers of $2.6 \mathrm{~km}^{2}$ around each observed and pseudo-absence nest site to represent breeding territory (Grier et al. 1983). We used the circular buffers to clip the raster data layers for elevation and landcover and calculated mean elevation and the proportion of water and sparse coniferous forest within each 
Table 2. Habitat and food variables incorporated into GIS layers for development of predictive habitat models for Bald Eagles (Haliaeetus leucocephalus) in Placentia Bay, NL. The codes are those used in Tables 4, 6, and 8. EOSD indicates Earth Observation for Sustainable Development of Forests.

\begin{tabular}{|c|c|c|c|c|}
\hline Data type & Code & Source & Year & Spatial Resolution \\
\hline Elevation & ELEV & $\begin{array}{l}\text { Canadian Digital Elevation Data, Natural Resources } \\
\text { Canada, Centre for Topographic Information }\end{array}$ & 2000 & $80 \mathrm{~m}$ pixel \\
\hline $\begin{array}{l}\text { Proportion sparse coniferous } \\
\text { forest }\end{array}$ & PSCF & $\begin{array}{l}\text { EOSD - Canadian Forest Service/Canadian Space } \\
\text { Agency }\end{array}$ & 2000 & $30 \mathrm{~m}$ pixel \\
\hline Proportion water & PW & $\begin{array}{l}\text { EOSD - Canadian Forest Service/Canadian Space } \\
\text { Agency }\end{array}$ & 2000 & $30 \mathrm{~m}$ pixel \\
\hline Islands & IS & CanVec Data & 2012 & Vector data \\
\hline $\begin{array}{l}\text { Distance to average capelin } \\
\text { (Mallotus villosus) spawning } \\
\text { beach }\end{array}$ & DACSB & $\begin{array}{l}\text { Department of Fisheries and Oceans Canada. Data are } \\
\text { based on traditional ecological knowledge as well as } \\
\text { data from federal and provincial fisheries and } \\
\text { conservation officers and a report by Sjare et al. (2003) }\end{array}$ & 2003 & Point data \\
\hline $\begin{array}{l}\text { Distance to major capelin } \\
\text { spawning beach }\end{array}$ & DMCSB & $\begin{array}{l}\text { Department of Fisheries and Oceans Canada. Data are } \\
\text { based on traditional ecological knowledge as well as } \\
\text { data from federal and provincial fisheries and } \\
\text { conservation officers and a report by Sjare et al. (2003) }\end{array}$ & 2003 & Point data \\
\hline $\begin{array}{l}\text { Distance to herring (Clupea } \\
\text { harengus) aggregation }\end{array}$ & DHA & $\begin{array}{l}\text { Department of Fisheries and Oceans Canada. Data are } \\
\text { based on traditional ecological knowledge as well as } \\
\text { data from federal and provincial fisheries and } \\
\text { conservation officers and a report by Sjare et al. (2003) }\end{array}$ & 2003 & Point data \\
\hline $\begin{array}{l}\text { Distance to capelin } \\
\text { aggregation }\end{array}$ & DCA & $\begin{array}{l}\text { Department of Fisheries and Oceans Canada. Data are } \\
\text { based on traditional ecological knowledge as well as } \\
\text { data from federal and provincial fisheries and } \\
\text { conservation officers and a report by Sjare et al. (2003) }\end{array}$ & 2003 & Point data \\
\hline
\end{tabular}

territory. We calculated the distance of each observed and pseudoabsence nest site to the nearest major and average capelin spawning beach using the near tool in ArcGIS, and we obtained the distance from each observed and pseudo-absence nest to the nearest capelin and herring aggregation site by using the extract values to points tool. Finally, we gave each nest a categorical value of 0 or 1 representing a mainland or island location.

\section{Statistical analysis}

We partitioned the data into two separate sets, using $10 \%$ of the occupied nest sites and $10 \%$ of the pseudo-absence data for validation (hereafter the "testing data") and the remainder of the data for training. We performed logistic regression analysis on the training data to describe the probability of a nest being built in an area based on the four habitat and four food resource parameters (Table 2). Thirteen generalized linear models using occupied vs. pseudo-absence locations as the dependent variable were tested and the best model was chosen based on the lowest QAICc value (to accommodate minor over dispersion; Burnham and Anderson 2002). The performance of the model was evaluated by generating prediction values from the testing data set and summarizing the results in a confusion matrix (showing false positives and false negatives from a single run with the testing date), from which we calculated correct classification rate, sensitivity, and specificity. We then used model averaging to identify the most important habitat and food variables for Bald Eagles and compared the value of these characteristics between occupied and pseudo-absence territories using Welch's t-test.

We created a second set of generalized linear models to describe the probability of a nest being active or occupied during $25 \%$ of the years surveyed based on the nest site habitat and food resource parameters. In this analysis we did not use the pseudo-absence data. Nests that were classified active or occupied $25 \%$ or more of the time were assigned a value of $1(n=83)$ while the remaining nests $(n=38)$ were assigned a value of 0 as the dependent variable in the logistic regression models. Once again the data set was partitioned into testing and training sets $(10 \%$ and $90 \%$ of the data, respectively). We used the same set of 13 models as above, and tested using the same procedure. The same procedure was used on a third set of generalized linear models that described the probability of a nest being active or occupied for at least $50 \%$ of the years surveyed. Similar to the models for nest sites above we computed indices of model accuracy (sensitivity and specificity) and used model averaging to identify the important habitat/food characteristics. These were compared using Welch's t-test, with nest site data partitioned four different ways. First, we compared sites with at least $25 \%$ overall nest sites active or occupied vs. sites with a rate of activity/occupancy of less than $25 \%$. A second test compared sites with at least $50 \%$ overall nest sites active or occupied $(n=52)$ vs. sites with a rate of activity/occupancy of less than $50 \%(n=69)$. We also compared those nest sites with $0 \%$ active or occupied $(n=26)$ against those with more than $25 \%$ as well as those nest sites with $0 \%$ active or occupied against those with more than $50 \%$ active or occupied. All statistical analysis was performed in $\mathrm{R}$ ( $\mathrm{v} 3.1 .0$ ).

\section{RESULTS}

Over the survey years, an average of 34.9 nest sites per year were observed, with an average $53.0 \%$ of these nest sites occupied (Table 3). The model that best predicted presence/absence was the global model, which had an Akaike weight of 0.99 . The $\Delta_{i}$ value for the next best model was 10.32 and is not considered to be a 
plausible model (Table 4). The global model predicted that nest occurrence was positively associated with nest site elevation, location on an island, distance to average capelin spawning beaches, and distance to herring aggregation sites, and negatively associated with the proportion of water, sparse coniferous forest, distance to major capelin spawning beaches, and distance to capelin aggregation sites (Table 5). The model had a correct classification rate of $51.7 \%$. The model had a high specificity of 0.882 but a sensitivity of 0 . Because the best model had an extremely high weight, model averaging was not necessary. Welch's t-test between occupied and unoccupied nest sites showed that only the value of the distance to the nearest major capelin spawning beach, and distance to nearest capelin aggregation were significantly different $(\mathrm{t}=2.7108, p=0.007$ and $\mathrm{t}=2.5259, p=$ 0.012 , respectively).

Table 3. Survey data by year for Placentia Bay, NL showing total nest sites observed, number of nest sites occupied, and $\%$ nest sites occupied.

\begin{tabular}{lccc}
\hline \hline Survey year & Total Nest Sites & $\begin{array}{c}\text { Occupied Nest } \\
\text { Sites }\end{array}$ & $\begin{array}{c}\text { \% Nest Sites } \\
\text { Occupied }\end{array}$ \\
\hline 1990 & 27 & 14 & 51.85 \\
1991 & 25 & 15 & 60.00 \\
1992 & 26 & 12 & 46.15 \\
1993 & 32 & 18 & 56.25 \\
1995 & 29 & 17 & 58.62 \\
1996 & 45 & 25 & 55.56 \\
1998 & 43 & 19 & 44.19 \\
2001 & 41 & 23 & 56.10 \\
2002 & 44 & 25 & 56.82 \\
2005 & 44 & 21 & 47.73 \\
2006 & 36 & 15 & 41.67 \\
2007 & 41 & 30 & 73.17 \\
2008 & 27 & 10 & 37.04 \\
2009 & 28 & 16 & 57.14 \\
\hline
\end{tabular}

The global model also best predicted $25 \%$ and $50 \%$ nest site activity/occupancy. However, out of the thirteen $25 \%$ activity/ occupancy models evaluated, eight models had $\Delta_{i}$ values less than 2 and one other model was less than 4 and for the $50 \%$ activity/ occupancy models there were four models with $\Delta_{i}$ values less than 2 and an additional four with values less than 4 , meaning that there are other models that are plausible beyond the global model. The Akaike weight of the "best" model to predict $25 \%$ nest site activity/occupancy was 0.17 (Table 6). This model predicted that nest site activity/occupancy is positively associated with nest site elevation, proportion of water, islands, distance to average capelin spawning beaches, and distance to capelin aggregation sites, and negatively associated with proportion of sparse coniferous forest, distance to major capelin spawning beaches, and distance to herring aggregation sites (Table 7). This model had a correct classification rate of $75.0 \%$. The model's specificity was 0.75 but because it failed to correctly predict the location of a true nest with activity/occupancy of $25 \%$ its sensitivity could not be calculated. The Akaike weight of the best model for predicting $50 \%$ nest site activity/occupancy was 0.24 (Table 8 ). This model predicted that nest site activity/occupancy was positively associated with proportion of water and sparse coniferous forest, islands, and distance to capelin aggregation sites, and negatively associated with nest site elevation, distance to average and major capelin spawning beaches, and distance to herring aggregation sites (Table 9). This model had a correct classification rate of $92.3 \%$. The model's specificity was 1 and its sensitivity was 0 .

Because other models are plausible for the $25 \%$ and $50 \%$ nest site activity/occupancy models, the relative importance of individual parameters were computed by using the sum of the Akaike weights for each parameter. In both cases distance to capelin and herring aggregation sites were rated the most important, closely followed by distance to major capelin spawning beaches, while proportion of water and sparse coniferous forest were rated least important (Tables 7 and 9), which is consistent with our prediction that habitat variables are less important in predicting nest activity/ occupancy than food variables. Welch's t-test for the food resources (those with highest parameter weights - distance to herring aggregation and distance to capelin aggregation) between sites with less than vs. higher than $25 \%$ activity/occupancy as well as between sites with $0 \%$ vs. higher than $25 \%$ nest activity/ occupancy showed no significant differences $(\mathrm{t}=0.067, p=0.947$ for distance to herring aggregation for nests over $25 \%$ vs. under $25 \% ; \mathrm{t}=-0.035, p=0.972$ for distance to capelin aggregation for nests over $25 \%$ vs. under $25 \%$; $=0.152, p=0.880$ for distance to herring aggregation for nests over $25 \%$ vs. under $0 \% ; \mathrm{t}=-0.022$, $p=0.982$ for distance to capelin aggregation for nests over $25 \%$ vs. $0 \%$ ). Similarly, Welch's t-test for the food resources (those with highest parameter weights - distance to herring aggregation and distance to capelin aggregation) between sites with less than vs. higher than $50 \%$ and between sites with $0 \%$ vs. higher than $50 \%$ nest activity/occupancy also showed no significant differences $(\mathrm{t}$ $=-0.782, p=0.436$ for distance to herring aggregation for nests over $50 \%$ vs. under $50 \%$; $\mathrm{t}=0.336, p=0.737$ for distance to capelin aggregation for nests over 50\% vs. under 50\%; $\mathrm{t}=-0.217, p=0.829$ for distance to herring aggregation for nests over $50 \%$ vs. under $0 \% ; \mathrm{t}=0.128, p=0.899$ for distance to capelin aggregation for nests over $50 \%$ vs. $0 \%$ ).

\section{DISCUSSION}

We found limited evidence to support our predictions that there would be differences in habitat attributes between occupied and unoccupied territories. Only distance to two food resources (distance to the nearest major capelin spawning beach, and distance to nearest capelin aggregation) were significantly different between occupied and unoccupied territories. However, both of these were negatively associated with the probability of a territory being occupied; unoccupied territories were closer to these resources than occupied ones. This does not provide sufficient evidence that Bald Eagles are food limited, as Hansen (1987) showed, and therefore it does not appear that habitat saturation is occurring, as least in terms of potential for eagles to occupy new territories. We found no evidence to support our prediction that there would be differences between sites with high vs. low or no nest activity/occupancy. None of the habitat or food resource values we examined differed between nest sites for either of the two $(25 \%$ and $50 \%)$ thresholds for nest activity/occupancy through time, which is in contrast to analysis of habitat differences of roosting sites in Chesapeake Bay (Beuhler et al. 1991). Therefore, we conclude there is currently no evidence for habitat saturation for Bald Eagles in Placentia Bay.

Our conclusion must be tempered by the fact that our predictive habitat models did not perform very well. The global model predicted differences between occupied and unoccupied nest sites 
Avian Conservation and Ecology 10(1): 4 http://www.ace-eco.org/vol10/iss1/art4/

Table 4. Model input, maximized log-likelihood (Log(lik)), number of estimated parameters (K), selection criterion (QAICc), simple differences $\left(\Delta_{i}\right)$, and Akaike weight for models predicting occupied vs. random territories for Bald Eagles (Haliaeetus leucocephalus) in Placentia Bay, NL. Model codes can be found in Table 2.

\begin{tabular}{lccccc}
\hline \hline Model & Log(lik) & $\mathrm{K}$ & QAICc & $\Delta_{i}$ & Akaike weight \\
\hline Global model & -152.87 & 9 & 223.17 & 0 & 0.987 \\
ELEV + IS + DACSB + DMCSB + DHA + DCA & -159.94 & 7 & 233.49 & 10.32 & 0.005 \\
ELEV + PSCF + PW + IS & -160.01 & 5 & 233.59 & 10.42 & 0.005 \\
IS + DACSB + DMCSB + DHA + DCA & -162.79 & 6 & 237.65 & 14.48 & $<0.001$ \\
IS + DMCSB + DHA + DCA & -163.93 & 5 & 239.32 & 16.15 & $<0.001$ \\
IS + DHA + DCA & -165.11 & 4 & 241.04 & 17.87 & $<0.001$ \\
ELEV + PSCF + PW + DACSB + DMCSB + DHA + DCA & -155.06 & 8 & 245.11 & 21.94 & $<0.001$ \\
ELEV + PSCF + PW & -162.23 & 4 & 247.08 & 23.91 & $<0.001$ \\
IS & -169.27 & 2 & 247.11 & 23.93 & $<0.001$ \\
DHA + DCA & -169.11 & 3 & 255.04 & 31.87 & $<0.001$ \\
DMCSB + DHA + DCA & -168.02 & 4 & 255.52 & 32.35 & $<0.001$ \\
DACSB + DMCSB + DHA + DCA & -167.34 & 5 & 256.62 & 33.45 & $<0.001$ \\
ELEV + DACSB + DMCSB + DHA + DCA & -165.95 & 6 & 256.71 & 33.54 & $<0.001$ \\
\hline
\end{tabular}

Table 5. Model coefficients and standard errors for the global model predicting nest site occurrence. Capelin, Mallotus villosus; herring, Clupea harengus.

\begin{tabular}{lcc}
\hline \hline Parameter & Model Coefficient & Standard Error \\
\hline Intercept & 0.565 & 1.113 \\
Elevation & 0.028 & 0.014 \\
Proportion water & -1.263 & 1.265 \\
Proportion sparse coniferous forest & -6.637 & 2.441 \\
Island & 0.699 & 0.338 \\
Distance to average capelin spawning & $5.277 \times 10^{-5}$ & $3.637 \times 10^{-5}$ \\
beach & $-1.324 \times 10^{-4}$ & $6.739 \times 10^{-5}$ \\
Distance to major capelin spawning beach & $1.133 \times 10^{-6}$ & $8.178 \times 10^{-5}$ \\
Distance to herring aggregation & $-4.116 \times 10^{-5}$ & $5.863 \times 10^{-5}$ \\
Distance to capelin aggregation & & \\
\hline
\end{tabular}

Table 6. Model input, maximized log-likelihood (Log(lik)), number of estimated parameters (K), selection criterion (QAICc), simple differences $\left(\Delta_{i}\right)$, and Akaike weight for models predicting 25\% Bald Eagle (Haliaeetus leucocephalus) nest site activity/occupancy over the 15 -years of survey data. Model codes can be found in Table 2.

\begin{tabular}{lccccc}
\hline \hline Model & $\log ($ lik $)$ & $\mathrm{K}$ & $\mathrm{QAICc}$ & $\Delta_{i}$ & Akaike weight \\
\hline Global model & -55.06 & 8 & 110.12 & 0.006 & 0.164 \\
ELEV + IS + DACSB + DMCSB + DHA + DCA & -55.06 & 6 & 110.13 & 0.006 & 0.164 \\
IS + DACSB + DMCSB + DHA + DCA & -55.07 & 5 & 110.15 & 0.025 & 0.163 \\
IS + DMCSB + DHA + DCA & -55.08 & 4 & 110.16 & 0.037 & 0.162 \\
ELEV + PSCF + PW + DACSB + DMCSB + DHA + DCA & -55.88 & 9 & 111.75 & 1.630 & 0.073 \\
ELEV + DACSB + DMCSB + DHA + DCA & -55.88 & 7 & 111.76 & 1.633 & 0.073 \\
DACSB + DMCSB + DHA + DCA & -55.88 & 6 & 111.76 & 1.640 & 0.073 \\
DMCSB + DHA + DCA & -55.88 & 5 & 111.76 & 1.641 & 0.073 \\
IS + DHA + DCA & -56.64 & 3 & 113.29 & 3.168 & 0.033 \\
DHA + DCA & -57.29 & 4 & 114.58 & 4.453 & 0.018 \\
ELEV + PSCF + PW + IS & -59.91 & 4 & 119.82 & 9.698 & 0.001 \\
ELEV + PSCF + PW & -60.70 & 5 & 121.39 & 11.270 & 0.001 \\
IS & -60.94 & 2 & 121.89 & 11.763 & $<0.001$ \\
\hline
\end{tabular}


Table 7. Model coefficients and standard errors for the global model predicting 25\% Bald Eagle (Haliaeetus leucocephalus) nest site activity/occupancy in Placentia Bay, NL and the sum of the Akaike weights for all parameters.

\begin{tabular}{lccc}
\hline \hline Parameter & Model Coefficient & Standard Error & $\begin{array}{c}\text { Parameter } \\
\text { Weighting }\end{array}$ \\
\hline Intercept & -1.087 & 2.314 & 0.477 \\
Elevation & $4.258 \times 10^{-3}$ & 0.029 & 0.240 \\
Proportion water & 0.058 & 2.491 & 0.240 \\
Proportion sparse coniferous forest & -0.382 & 7.561 & 0.690 \\
Island & 0.863 & 0.715 & 0.711 \\
Distance to average capelin spawning beach & $7.902 \times 10^{-6}$ & $6.116 \times 10^{-5}$ & 0.946 \\
Distance to major capelin spawning beach & $-2.051 \times 10^{-4}$ & $1.235 \times 10^{-4}$ & 0.998 \\
Distance to herring aggregation & $-5.076 \times 10^{-4}$ & $2.324 \times 10^{-4}$ & 0.998 \\
Distance to capelin aggregation & $1.302 \times 10^{-4}$ & $1.199 \times 10^{-4}$ & \\
\hline
\end{tabular}

Table 8. Model input, maximized log-likelihood ( $\log (\mathrm{lik}))$, number of estimated parameters (K), selection criterion (QAICc), simple differences $\left(\Delta_{i}\right)$ and Akaike weight for models predicting 50\% Bald Eagle (Haliaeetus leucocephalus) nest site activity/occupancy over the 15-years of survey data. Model codes can be found in Table 2.

\begin{tabular}{|c|c|c|c|c|c|}
\hline Model & $\log ($ lik $)$ & $\mathrm{K}$ & QAICc & $\Delta_{i}$ & Akaike weight \\
\hline Global model & -12.81 & 9 & 25.61 & 0.83 & 0.175 \\
\hline $\mathrm{ELEV}+\mathrm{IS}+\mathrm{DACSB}+\mathrm{DMCSB}+\mathrm{DHA}+\mathrm{DCA}$ & -13.22 & 7 & 26.44 & 0.83 & 0.175 \\
\hline IS + DACSB + DMCSB + DHA + DCA & -13.41 & 6 & 26.82 & 1.21 & 0.145 \\
\hline $\mathrm{IS}+\mathrm{DMCSB}+\mathrm{DHA}+\mathrm{DCA}$ & -13.52 & 5 & 27.03 & 1.42 & 0.130 \\
\hline $\mathrm{ELEV}+\mathrm{PSCF}+\mathrm{PW}+\mathrm{DACSB}+\mathrm{DMCSB}+\mathrm{DHA}+\mathrm{DCA}$ & -13.90 & 8 & 27.81 & 2.20 & 0.088 \\
\hline $\mathrm{ELEV}+\mathrm{DACSB}+\mathrm{DMCSB}+\mathrm{DHA}+\mathrm{DCA}$ & -14.04 & 6 & 28.08 & 2.47 & 0.077 \\
\hline $\mathrm{IS}+\mathrm{DHA}+\mathrm{DCA}$ & -14.06 & 4 & 28.12 & 2.51 & 0.076 \\
\hline $\mathrm{DACSB}+\mathrm{DMCSB}+\mathrm{DHA}+\mathrm{DCA}$ & -14.51 & 5 & 29.02 & 3.41 & 0.048 \\
\hline $\mathrm{DMCSB}+\mathrm{DHA}+\mathrm{DCA}$ & -14.87 & 4 & 29.74 & 4.13 & 0.034 \\
\hline DHA + DCA & -15.32 & 3 & 30.64 & 5.03 & 0.021 \\
\hline $\mathrm{ELEV}+\mathrm{PSCF}+\mathrm{PW}+\mathrm{IS}$ & -15.73 & 5 & 31.46 & 5.85 & 0.014 \\
\hline IS & -16.13 & 2 & 32.26 & 6.65 & 0.009 \\
\hline $\mathrm{ELEV}+\mathrm{PSCF}+\mathrm{PW}$ & -16.72 & 4 & 33.44 & 7.83 & 0.005 \\
\hline
\end{tabular}

Table 9. Model coefficients and standard errors for the global model predicting 50\% Bald Eagle (Haliaeetus leucocephalus) nest site activity/occupancy in Placentia Bay, NL and the sum of the Akaike weights for all parameters.

\begin{tabular}{lccc}
\hline \hline Parameter & Model Coefficient & Standard Error & $\begin{array}{c}\text { Parameter } \\
\text { Weighting }\end{array}$ \\
\hline Intercept & -28.690 & 3131.000 & 0.535 \\
Elevation & -0.014 & 0.083 & 0.283 \\
Proportion water & 7.065 & 8.245 & 0.283 \\
Proportion sparse coniferous forest & 18.620 & 24.330 & 0.725 \\
Island & 18.870 & 3131.000 & 0.709 \\
Distance to average capelin spawning beach & $-9.448 \times 10^{5}$ & $3.120 \times 10^{-4}$ & 0.873 \\
Distance to major capelin spawning beach & $-2.161 \times 10^{-4}$ & $3.012 \times 10^{-4}$ & 0.971 \\
Distance to herring aggregation & $-3.723 \times 10^{-4}$ & $5.530 \times 10^{-4}$ & 0.971 \\
Distance to capelin aggregation & $5.519 \times 10^{-4}$ & $3.622 \times 10^{-4}$ & \\
\hline
\end{tabular}


with an AIC weight of 0.99 (Table 4), but when validated, the correct classification rate was not different from chance $(51.7 \%)$. The global model was very good at predicting nest presence (sensitivity of 0.882 ) but very poor at predicting nest absence (specificity of 0). Models to predict nest activity/occupancy levels above and below $25 \%$ and $50 \%$, respectively (i.e., there were no pseudo-absence points in the training data) were more equivocal, with no one model dominant (Tables 6 and 8). Model averaging suggested that food resources were more important in predicting nest activity/occupancy than habitat characteristics, which is consistent with our predictions about food being a more limiting resource that can, in some cases, drive habitat saturation. The models for nest activity/occupancy had high overall classification accuracy ( $75 \%$ and $92 \%$, respectively) but performed poorly with respect to the ability to predict nests with low activity/occupancy rates (specificity of 0 for both models).

The lack of model specificity suggests that there are environment, habitat, or food resource variables missing from our models. For example, in a study in Maine, Livingston et al. (1990) examined over 25 different variables; we examined only 8 (Table 2 ). There was some indication that food resources may be more important in predicting whether a territory is occupied or not, but there was no significant difference between the values for food resources in territories with a high vs. low nest activity/occupancy. Given the broad diet of this species, it is likely we have not captured food resource data in our model, which is a common challenge (e.g., McCue et al. 2014). If there are elements that are important to Bald Eagles that are missing from the habitat models, it is possible that habitat saturation is occurring in Placentia Bay, but we have not detected it. For example, we only measured two marine resources (capelin and herring), both of which are highly ephemeral sources of food. Moreover unlike capelin, which are beach spawners, herring may only be easy for Bald Eagles to catch when they are spawning in shallow water. We did not include water depth in our models; this may be important for predicting foraging opportunities. Other marine prey species are available in the bay (such as sea birds; Dominguez 1998), and Bald Eagles elsewhere have been shown to be generalists foraging on a wide range of prey (Anthony et al. 2008, Markham and Watts 2008) including postspawn salmon carcasses (Harvey et al. 2012). As well, prey resources in this area are highly dynamic. During the study period commercial fish stocks in the area have undergone significant fluctuations (Robichaud and Rose 2006). This is reflected in the closure of the Atlantic commercial cod fishery from 1993 to 1996. Both prey abundance and commercial fishing have been found to be positively correlated with Bald Eagle productivity (Hoff et al. 2004). Whether the fluctuating prey abundance and fishing activity in Placentia Bay has been having an effect on the Bald Eagle breeding density is unknown and further research is needed to test whether food availability can explain the increase in nonbreeding adults.

Alternative hypotheses for the increasing and high proportion of nonbreeding adults in the Placentia Bay population include the possibility that the population has experienced release from predation; the possibility that the population is undergoing recovery following bans of DDT in North America; or the possibility that the observed population changes are an artifact of experimental design.

\section{Predation release}

Although Newfoundland has never issued a bounty on Bald Eagles, (over 128,000 bounties were paid in Alaska from 1917 to 1952 [Buehler 2000]), one of us (JB) has noted some reported cases of intentional shooting during the survey years throughout the province. Accurate data on intentional shooting is not available for Newfoundland. However, the U.S. Geological Survey's National Wildlife Health Center determined that out of 1428 Bald Eagles necropsied from 1963-1984, 22\% died from gunshot (Buehler 2000). With an increase in public education on wildlife conservation and improved law enforcement, it is expected that the percentage of Bald Eagle deaths as a result of shooting has decreased dramatically across the continent in the last 30 years, aiding in the population increase (Buehler 2000). With fewer settlements in Placentia Bay following government relocation programs in the 1960 s and the closure of the cod fishery in the 1990s, it is possible that human persecution of Bald Eagles in the region has decreased, and resulted in the observed high proportion of nonbreeding adults in the population. However, without accurate historical data on Bald Eagle deaths due to shooting, it is impossible to test this hypothesis.

\section{Recovery following DDT bans}

The mean finite multiplication rate $(\lambda)$ for the population of Bald Eagles in Placentia Bay during the breeding seasons of 1990-2009 suggests that on average the population is increasing by $15 \%$ a year (Letto 2010). This is similar or greater than the increase that has been observed across North America following the ban of DDT (Kirk and Hyslop 1998). The former U.S. Naval Base, located in nearby Argentia ceased operation in 1994. Results from a 1996-1997 study found that DDE and PCB concentrations were negatively related to nest distance from the former naval base (Dominguez et al. 2003). However, Dominguez et al. (2003) reported that concentrations of PCBs, DDE, and mercury in Placentia Bay's Bald Eagle population were below the threshold for reproductive impairment. Although the plasma concentrations at this time were below the threshold to limit Bald Eagle productivity there is still a possibility that contaminant levels within the area were high enough in the 1970s and 1980s to negatively affect the population. If this is the case then the increase in the population may be an artefact of the more recent decrease in contamination levels.

\section{Experimental design}

Finally, the observed increase in nonbreeding adults may be due to experimental design. Given that the surveys were all conducted by boat, instead of more commonly used aerial surveys (Anthony et al. 1999, Wilson et al. 2014), it is possible observers could have missed active nest sites and that some of the observed adults were in fact associated with an unobserved nest and hence incorrectly identified as nonbreeders. However, in 1996 the Wildlife Division conducted an aerial survey along the coast and inland for comparison purposes with the boat survey and to assess whether there were any nests inland that would not be visible with boat surveys. Their analysis found no difference in census results, both in terms of population and nest sites. However, preliminary telemetry studies conducted by JB and BR (based on 3 individuals over 2 years) show that nonbreeding adult Bald Eagles in Newfoundland travel a mean daily distance of $17.7 \mathrm{~km}$ during the nesting season (May to July), although individual maximum 
daily travel distances exceeded $125 \mathrm{~km}$ for all 3 birds that were tagged. Therefore, some individuals counted in our surveys may not belong to the Placentia Bay population and experimental design and survey methods are a plausible alternative hypothesis for observed population trends here. Moreover, a larger sample size, in conjunction with manipulative food experiments, e.g., food additions, would provide better data for a test of the habitat saturation hypothesis.

\section{CONCLUSIONS}

The population trends observed in Placentia Bay are consistent with Bald Eagle population trends from across Canada (Kirk and Hyslop 1998) and many parts of North America, and are mostly attributed to the recovery of Bald Eagle chick production following the ban of DDT (Grier 1982, Kirk and Hyslop 1998). However, in Alaska, Hansen and Hodges (1985) dismissed the hypotheses that the high proportion of nonbreeding adults they observed was due to depressed breeding rates because of chemical contamination (their surveys were in 1970-1972 and 1979; and DDT was only banned in the United States in 1972). They argued that eagles in southeastern Alaska had not accumulated the same levels of organochlorines as observed in southern Bald Eagle populations that had undergone significant reductions in egg and eaglet production during the DDT era (Hansen and Hodges 1985) and instead hypothesized that the large proportion of adult nonbreeders was due to either food and/or habitat limitations. Hansen (1987) tested the food and habitat limitation hypothesis in Alaska using a correlation analysis and a food addition experiment. He found that two habitat characteristics (elevation of nest tree above water and height class of nest tree), together with food abundance, were significantly correlated with a higher amount of breeding activity, measured as proportion of active nests (Hansen 1987). Because nonbreeding adults are able to forage over vast distances while breeders must remain close to their nest sites, an area with spatially and temporally variable food resources, as is the norm in Alaska and in Placentia Pay, is able to support a high overall density of adults, but a lower proportion of breeding adults (Hansen 1987). This in turn results in a surplus of nonbreeding adults. For this reason, Hansen (1987) concluded that there are a limited number of suitable nest sites, and that once suitable nest sites became saturated with breeding pairs, other adults opt out of breeding that year instead of attempting to nest in less suitable areas.

Placentia Bay is similar to Alaska in that there is little evidence that DDT or other environmental contaminants would have impaired reproduction (Dominguez et al. 2003). However, unlike Hansen (1987), we only found evidence that food resources might limit which territories are occupied. We found no evidence of differences in elevation of nest site above water or of distance to food resources between occupied vs. unoccupied territories or between nests with high vs. low nest activity/occupancy rates. We conclude that there is currently no strong evidence for habitat saturation for Bald Eagles in Placentia Bay. However, more indepth research into spatial and temporal variability in a wider array of food resources than we examined here may yield different results.

Bald Eagles are charismatic birds that can occupy a wide array of habitat types. Across their range there are similarities and differences in their populations and habitat use. For example, the increasing and high proportion of nonbreeding adults has been observed in Alaska (Hansen and Hodges 1985, Zwiefelhofer 2007) and the Pacific Northwest (Elliott et al. 2011), in boreal and temperate coastal areas (Placentia and Chesapeake Bay; Jenkins and Sherrod 2005), in central North America (Mougeot et al. 2013), and in desert environments (Arizona; Driscoll et al. 1999). The reasons for similarities in these trends may or may not be the same in all regions; possible mechanisms include climate, densitydependent limitations, habitat loss, human-caused mortality, and winter mortality. Careful site-specific research to inform conservation and management is necessary.

Responses to this article can be read online at: http://www.ace-eco.org/issues/responses.php/729

\section{Acknowledgments:}

Field work was funded by the Government of Newfoundland and Labrador, Wildlife Division with support from the Department of Natural Resources. Field work was carried out with the assistance of Tim Andrews, Shawn Avery, Ed Loder, Dave Slade, Conrad Smith, Eric Sullivan, and other representatives from the Department of Natural Resources, Memorial University, and the Canadian Wildlife Service. Marine food resource spatial data was provided by Fisheries and Oceans Canada. During the time of this research, KL was supported by an NSERC USRA. Data analysis was carried out with support from NSERC Discovery and Canadian Foundation for Innovation Grants to YFW.

\section{LITERATURE CITED}

Andrew, J. M., and J. A. Mosher. 1982. Bald Eagle nest site selection and nesting habitat in Maryland. Journal of Wildlife Management 46:382-390. http://dx.doi.org/10.2307/3808650

Anthony, R. G., M. G. Garrett, and F. B. Isaacs. 1999. Doublesurvey estimates of Bald Eagle populations in Oregon. Journal of Wildlife Management 63:794-802. http://dx.doi.org/10.2307/3802792

Anthony, R. G., J. A. Estes, M. A. Ricca, A. K. Miles, and E. D. Forsman. 2008. Bald eagles and sea otters in the Aleutian archipelago: indirect effects of trophic cascades. Ecology 89:2725-2735. http://dx.doi.org/10.1890/07-1818.1

Austin, M. P. 2002. Spatial prediction of species distribution: an interface between ecological theory and statistical modelling. Ecological Modelling 157:101-118. http://dx.doi.org/10.1016/ S0304-3800(02)00205-3

Baldwin, J. D., J. W. Bosley, L. Oberfofer, O. L. Bass, and B. K. Mealey. 2012. Long-term changes, 1958-2010, in the reproduction of Bald Eagles of Florida Bay, southern coastal Everglades. Journal of Raptor Research 46:336-348. http://dx.doi.org/10.3356/ JRR-11-65.1

Brown, J. L. 1969. Territorial behaviour and population regulation in birds: a review and re-evaluation. Wilson Bulletin 81:293-329.

Buehler, D. A. 2000. Bald Eagle (Haliaeetus leucocephalus). No. 506 in A. Poole and F. Gill, editors. The birds of North America. The Birds of North America, Philadelphia, Pennsylvania USA. 
Buehler, D. A., T. J. Mersmann, J. D. Fraser, and J. K. D. Seegar. 1991. Nonbreeding Bald Eagle communal and solitary roosting behaviour and roost habitat on the northern Chesapeake Bay. Journal of Wildlife Management 55:273-281. http://dx.doi. org/10.2307/3809150

Burnham, K. P., and D. R. Anderson. 2002. Model selection and multi-model inference: a practical information-theoretic approach. Second edition. Springer, New York, USA.

Canadian Centre for Marine Communications (CCMC). 2004. Placentia Bay information seaway pilot project - stakeholder workshop. CCMC, Memorial University, St. John's, Newfoundland and Labrador, Canada. [online] URL: http://www.smartatlantic. ca/documents/user\%20workshop\%20report $\% 20-\% 20$ march $\% 2028$. pdf

Damman, A. W. H. 1983. An ecological subdivision of the Island of Newfoundland. Pages 163-206 in G. R. South, editor. Biogeography and ecology of the island of Newfoundland. Kluwer Academic, Dordrecht, The Netherlands.

Dominguez, L. 1998. Reproductive success and environmental contaminants among Bald Eagles in Placentia and Bonavista Bays, Newfoundland. Thesis, Memorial University, St. John's, Newfoundland and Labrador, Canada.

Dominguez, L., W. A. Montevecchi, N. M. Burgess, J. Brazil, and K. A. Hobson. 2003. Reproductive success, environmental contaminants and trophic status of nesting Bald Eagles in eastern Newfoundland, Canada. Journal of Raptor Research 37:209-218.

Driscoll, D. E., R. E. Jackman, W. G. Hunt, G. L. Beatty, J. T. Driscoll, R. L. Glinski, T. A. Gatz, and R. I. Mesta. 1999. Status of nesting Bald Eagles in Arizona. Journal of Raptor Research $33: 218-226$.

Dzus, E. H., and J. M. Gerrard. 1989. Interlake variations of Bald Eagle, Haliaeetus leucocephalus, populations in North-central Saskatchewan. Canadian Field-Naturalist 103:29-33.

Elliott, K. H., J. Duffe, S. L. Lee, P. Mineau, and J. E. Elliott. 2006. Foraging ecology of Bald Eagles at an urban landfill. Wilson Journal of Ornithology 118:380-390. http://dx.doi.org/10.1676/04-126.1

Elliott, K. H., J. E. Elliott, L. K. Wilson, I. Jones, and K. Stenerson. 2011. Density-dependence in the survival and reproduction of Bald Eagles: linkages to chum salmon. Journal of Wildlife Management 75:1688-1699. http://dx.doi.org/10.1002/ jwmg.233

Emlen, S. T. 1982. The evolution of helping. I. An ecological constraints model. American Naturalist 119:29-39. http://dx.doi. org/10.1086/283888

Fielding, A. H., and J. F. Bell. 1997. A review of methods for the assessment of prediction errors in conservation presence/absence models. Environmental Conservation 24:38-49. http://dx.doi. org/10.1017/S0376892997000088

Gende, S. M., M. F. Wilson, and M. Jacobsen. 1997. Reproductive success of Bald Eagles (Haliaeetus leucocephalus) and its association with habitat or landscape features and weather in southeast Alaska. Canadian Journal of Zoology 75:1595-1604. http://dx.doi.org/10.1139/z97-786
Gerrard, J. M., P. Gerrard, W. J. Maher, and D. W. A. Whitfield. 1975. Factors influencing nest site selection of Bald Eagles in northern Saskatchewan and Manitoba. Blue Jay 33:169-176.

Gerrard, J. M., P. N. Gerrard, G. R. Bortolotti, and E. H. Dzus. 1992. A 24-year study of Bald Eagles on Besnard Lake, Saskatchewan. Journal of Raptor Research 26:159-166.

Grier, J. W. 1982. Ban of DDT and subsequent recovery of reproduction in Bald Eagles. Science 218:1232-1235. http://dx. doi.org/10.1126/science.7146905

Grier, J. W., J. B. Elder, F. J. Gramlich, N. F. Green, J. V. Kussman, J. E. Mathisen, and J. P. Mattsson. 1983. Northern states Bald Eagle recovery plan. Northern States Bald Eagle Recovery Team (U.S.), U.S. Fish and Wildlife Service, Denver, Colorado, USA.

Hansen, A. J. 1987. Regulation of Bald Eagle reproductive rates in southeast Alaska. Ecology 68:1387-1392. http://dx.doi. org/10.2307/1939222

Hansen, A. J., and J. I. Hodges, Jr. 1985. High rates of nonbreeding adult Bald Eagles in southeastern Alaska. Journal of Wildlife Management 49:454-458. http://dx.doi.org/10.2307/3801551

Harvey, C. J., P. E. Moriary, and E. P. Salathé, Jr. 2012. Modeling climate change impacts on overwintering Bald Eagles. Ecology and Evolution 2:501-514. http://dx.doi.org/10.1002/ece3.204

Hodges, J. I., J. G. King, and R. Davies. 1984. Bald Eagle breeding population survey of coastal British Columbia. Journal of Wildlife Management 48:993-998. http://dx.doi.org/10.2307/3801455

Hoff, M. H., M. W. Meyer, J. Van Stappen, and T. W. Fratt. 2004. Relationship between Bald Eagle productivity and dynamics of fish populations and fisheries in the Wisconsin waters of Lake Superior, 1983-1999. Journal of Great Lakes Research 30:434-442. http://dx.doi.org/10.1016/S0380-1330(04)70404-9

Jenkins, M. A., and S. K. Sherrod. 2005. Growth and recovery of the Bald Eagle population in Oklahoma. Wildlife Society Bulletin 33:810-813. http://dx.doi.org/10.2193/0091-7648(2005)33[810:GAROTB] 2.0.CO;2

Kimball, R. T., P. G. Parker, and J. C. Bednarz. 2003. Occurrence and evolution of cooperative breeding among the dirurnal raptors (Accipitridae and Falconidae). Auk 120:717-729. http://dx.doi. org/10.1642/0004-8038(2003)120[0717:OAEOCB]2.0.CO;2

Kirk, D. A., and C. Hyslop. 1998. Population status and recent trends in Canadian raptors: a review. Biological Conservation 83:91-118. http://dx.doi.org/10.1016/S0006-3207(97)00051-7

Koenig, W. D., F. A. Pitelka, W. J. Carmen, R. L. Mumme, and M. T. Stanback. 1992. The evolution of delayed dispersal in cooperative breeders. Quarterly Review of Biology 67:111-150. http://dx.doi.org/10.1086/417552

Letto, K. R. 2010. An assessment of breeding Bald Eagle (Haliaeetus leucocephalus) nest density and distribution in Placentia Bay, Newfoundland in relation to habitat and food availability (1990-2009). Thesis, Memorial University, St. John's, Newfoundland and Labrador, Canada.

Livingston, S. A., C. S. Todd, W. B. Krohn, and R. B. Owen, Jr. 1990. Habitat models for nesting Bald Eagles in Maine. Journal of Wildlife Management 54:644-653. http://dx.doi.org/10.2307/3809363 
Markham, A. C., and B. D. Watts. 2008. The influence of salinity on the diet of nesting Bald Eagles. Journal of Raptor Research 42:99-109. http://dx.doi.org/10.3356/JRR-05-62.1

McCue, A. J., M. J. McGrath, and Y. F. Wiersma. 2014. Benefits and drawbacks of two modelling approaches for a generalist carnivore: can models predict where Wile E. Coyote will turn up next? Special Issue: Spatial Ecology International Journal of Geographic Information Science 28:1590-1609. http://dx.doi. org/10.1080/13658816.2013.847444

Millsap, B., T. Breen, E. McConnell, T. Steffer, L. Phillips, N. Douglass, and S. Taylor. 2004. Comparative fecundity and survival of Bald Eagles fledged from suburban and rural natal areas in Florida. Journal of Wildlife Management 68:1018-1031. http://dx.doi.org/10.2193/0022-541X(2004)068[1018:CFASOB]2.0. $\mathrm{CO} ; 2$

Mougeot, F., J. Gerrard, E. Dzus, B. Arroyo, P. N. Gerrard, C. Dzus, and G. Bortolotti. 2013. Population trends and reproduction of Bald Eagles at Besnard Lake, Saskatchewan, Canada 1968-2012. Journal of Raptor Research 47:96-107. http:// dx.doi.org/10.3356/JRR-12-45.1

Phillips, S. J., M. Dudík, J. Elith, C. H. Graham, A. Lehmann, J. Leathwick, and S. Ferrier. 2009. Sample selection bias and presence-only distribution models: implications for background and pseudo-absence data. Ecological Applications 19:181-197. http://dx.doi.org/10.1890/07-2153.1

Robichaud, D., and G. A. Rose. 2006. Density-dependent distribution of demersal juvenile Atlantic cod (Gadus morhua) in Placentia Bay, Newfoundland. Journal of Marine Science 63:766-774. http://dx.doi.org/10.1016/j.icesjms.2005.12.002

Sherrod, S. K., C. M. White, and F. S. L. Williamson. 1976. Biology of the Bald Eagle on Amchitka Island, Alaska. Living Bird 15:145-182.

Sjare, B., B. Nakashima, and D. Mercer. 2003. Integrating scientific and local ecological knowledge to identify potential critical habitats: a case study in Placentia Bay, Newfoundland. Canadian Science Advisory Secretariat, Ottawa, Ontario, Canada. [online] URL: http://www.dfo-mpo.gc.ca/CSAS/Csas/ DocREC/2003/RES2003_114_e.pdf

Swenson, J. E., K. L. Alt, and R. L. Eng. 1986. Ecology of Bald Eagles in the greater Yellowstone ecosystem. Wildlife Monographs 95:3-46.

Thompson, C. M., and K. McGarigal. 2002. The influence of research scale on Bald Eagle habitat selection along the lower Hudson River, New York (USA). Landscape Ecology 17:569-586. http://dx.doi.org/10.1023/A:1021501231182

Watts, B. D., and A. E. Duerr. 2010. Nest turnover rates and listframe decay in Bald Eagles: implications for the National Monitoring Plan. Journal of Wildlife Management 74:940-944. http://dx.doi.org/10.2193/2009-018
Watts, B. D., G. D. Therres, and M. A. Byrd. 2008. Recovery of the Chesapeake Bay Bald Eagle nesting population. Journal of Wildlife Management 72:152-158. http://dx.doi.org/10.2193/2005-616

Wilson, T. L., J. H. Schmidt, W. L. Thompson, and L. M. Phillips. 2014. Using double-observer aerial surveys to monitor nesting Bald Eagles in Alaska: are all nests available for detection? Journal of Wildlife Management 78:1096-1103. http://dx.doi.org/10.1002/ jwmg.753

Zwiefelhofer, D. 2007. Comparison of Bald Eagle (Haliaeetus leucocephalus) nesting and productivity at Kodiak National Wildlife Refuge, Alaska, 1963-2002. Journal of Raptor Research 41:1-9. http://dx.doi.org/10.3356/0892-1016(2007)41[1:COBEHL] 2.0.CO;2
Editor-in-Chief: Keith A.Hobson Subject Editor: Alexander L.Bond
Sponsored by the Society of Canadian Ornithologists and Bird Studies Canada Parrainée par la Société des ornithologistes du Canada et Études d'oiseaux Canada

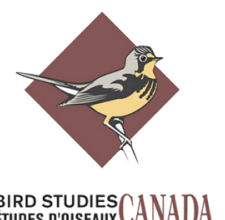

